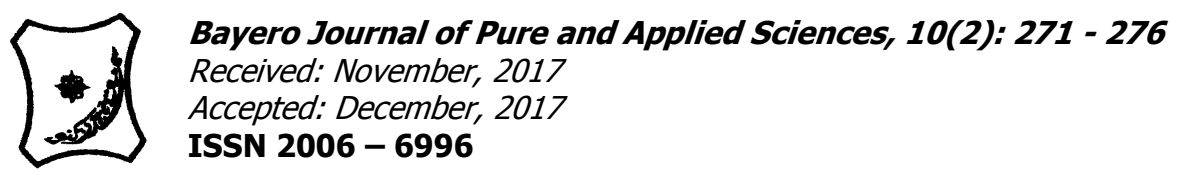

\title{
GENETIC STUDIES OF AGRONOMIC AND KERNEL QUALITY TRAITS IN WHITE MAIZE (Zea mays L.) INBRED LINES
}

\author{
Dawaki, K.D., ${ }^{1 *}$ Yusuf, M., ${ }^{2}$ Ibrahim, A.K. ${ }^{3}$ and Bala, A. ${ }^{4}$ \\ ${ }^{1}$ Department of Crop Production Technology, Audu Bako College of Agriculture, Dambatta. P.M.B 3159, Kano State, \\ Nigeria \\ ${ }^{2}$ Department of Plant Science, Ahmadu Bello University, Zaria. Kaduna State, Nigeria \\ ${ }^{3}$ Department of Agronomy, Bayero University. Kano. P. M.B. 3011, Kano-Nigeria \\ ${ }^{4}$ Department of Forestry Technology, Audu Bako College of Agriculture, Dambatta. \\ P.M.B 3159, Kano State, Nigeria \\ *Corresponding author: kabirudawaki@gmail.com; Phone: +2348024794501
}

\begin{abstract}
Field experiments were conducted at National Horticultural Research Institute, Bagauda (11 ${ }^{\circ} 33^{\prime} N$; $\left.8^{\circ} 23^{\prime} \mathrm{E}\right)$ in the Sudan Savannah and Institute for Agricultural Research, Samaru (11 $\left.11^{\prime} \mathrm{N} ; 07^{\circ} 38^{\prime} \mathrm{E}\right)$ in the Northern Guinea Savanna ecological zones of Nigeria. The experiments were conducted between July-October, 2014 rainy season to estimates mean squares for general combining ability (GCA), specific combining ability( SCA) and interaction between general combining ability and location (GCA $x$ location) and specific combining ability and location Interactions (SCA x location) for agronomic traits and kernel quality traits. The study comprised of 15 hybrid lines, 6 parental lines along with 4 checks which were laid out in partially balanced lattice design with three replications. Analysis of variance revealed significant ( $P \leq 0.01)$ GCA for days to maturity $(27.74)$, ear length $(8.85 \mathrm{~cm})$, ear diameter $(22.25 \mathrm{~cm})$, plant height $(1501.60 \mathrm{~cm})$, field weight $(1.70 \mathrm{~kg})$, moisture content at harvest $(16.48 \%)$ and yield (10947553.16 $\mathrm{kgha}^{-1}$ ) indicating the additive gene action contributing the expression of

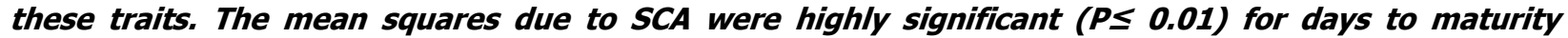
(7.49), ear length $(10.06 \mathrm{~cm})$, ear diameter $(26.96 \mathrm{~cm})$ and moisture content at harvest $(6.78 \%)$ indicating the preponderance of non-additive gene action in the expression of these traits. The mean squares for GCAX location and SCAX location were not significant for all traits except percent whole kernel which shows highly significant GCA $\times$ location interaction (2077.97\%) and this indicated that, different parental genotypes behaved differently with respect to this trait under different location.

KEYWORDS: Agronomic traits, Genetic, General Combining Ability, Inbred lines, Kernel Quality and Specific Combining Ability
\end{abstract}

\section{INTRODUCTION}

Maize or corn (Zea mays L.), belongs to the grass family Poaceae and tribe Maydeae, originated 5000 to 10,000 years ago (Hallauer, 1997; Paliwal and Smith, 2002). The origin of maize is controversial; however, it is believed to have originated in the mid-altitude regions of Mexico and Guatemala or Mesoamerica (Paliwal and Smith, 2002). It is one of the three most important cereal crops in the world together with wheat and rice. In industrialized countries, it is largely used as livestock feed and as a raw material for industrial products, while in developing countries, it is mainly used for human consumption. Africans consume maize as a starchy base in a wide variety of porridges, pastes, grits, and beer. In sub-Saharan Africa, it is a staple food for an estimated $50 \%$ of the population. It is an important source of carbohydrate, protein, iron, vitamin B, and minerals
(Dilip et al.,2013). It is fast becoming a very important commodity in animal feed, food and beverage industries (USAID, 2010). Worldwide maize is cultivated in an area of 159 million hectares with a production of 796.46 million metric tons (USDA, 2010). Accordingto FAOSTAT (2014). The area in West African countries planted to maize increased from 3.2 million hectares in 1961 to 8.9 million hectares in 2005. The United States is the world's largest producer and exporter of maize with a corn production volume amounting to about 385 million metric tons with total of $96,000,000$ acres of land in 2017-2018 (USDA 2018). Other top producing countries include China, Brazil, Mexico, Argentina, India and France. Nigeria is the 10th largest producer of maize in the world, and the main producing country in tropical Africa (USAID, 2010). 
It is cultivated both as rain fed and under irrigation on more than 5 million hectares, spread through the six agro-ecological zones and maize production is put at about 26 million tons from 3,845,000 hectares (FAO, 2009). In Africa, maize is grown by small- and mediumscale farmers who cultivate 10 hectares or less (DeVries and Toenniessen, 2001) under extremely low-input systems where average yield is 1.3 tons ha ${ }^{-1}$ (Bänziger and Diallo, 2004). It is essential to have knowledge of the nature and magnitude of genetic variability created through hybridization for various traits, since the nature and magnitude of variability are pre-requisite for any crop improvement which would assist breeders in planning successful breeding program. Estimation for General and Specific Combining Ability mean squares are useful for detecting the degree of variability among genotypes. The objectives of the present study were (i) to estimate the variability and type of gene action in the white maize inbred lines for General Combining Ability (GCA), Specific Combining Ability (SCA), General Ability by location (GCA $x$ location) and Specific Combining Ability by location Interactions (SCA $x$ location) for agronomic and kernel quality traits and (ii) to evaluate suitable selection criteria for further breeding.

\section{MATERIALS AND METHODS}

The experiment consists of 6 white maize inbred lines which were crossed using half diallel mating design. The

$$
y_{i j k t}=\mu+g_{i}+g_{j}+S_{i j}+l_{t}+(g l)_{i t}+(s l)_{i j t}+r_{k t}+e_{i j k t}
$$

Where:

$y_{i j k}=$ The yield of a cross between $i^{\text {th }}$ and $j^{\text {th }}$ parent in the $k^{\text {th }}$ replication in the $t^{\text {th }}$ location.

$\mu=$ Overall mean

$g_{i}=$ Effect common to all progeny of the $i^{t h}$ parent

$g_{j}=$ Effect common to all progeny of the $j^{\text {th }}$ parent

$S_{i j}=$ Effect specific to the progeny of mating $i^{\text {th }}$ and $j^{\text {th }}$ parents

$l_{t}=$ The average effect of the $t^{t h}$ location

$(g l)_{i t}=$ Genotype $x$ location interaction effect in the $i^{\text {th }}$ parent in that location

$(g l)_{j t}=$ Genotype $x$ location interaction effect in the $j^{\text {th }}$ parent in that location

$(s l)_{i j t}=$ Specific effect of mating $i^{t h}$ parent and $j^{\text {th }}$ parent in that location.

$r_{k t}=$ Effect of the $k$ replication in $t$ location

$e_{i j t}=$ Experimental error

$i=1-6$ parents

$j=1-6$ parents

$k=1-3$ replications

$l=1-2$ locations
15 hybrids, 6 parents and 4 checks were evaluated at National Horticultural Research Institute, Bagauda

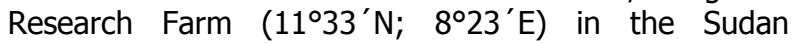
Savannah and Institute for Agricultural Research Farm, Samaru $\left(11^{0} 11^{\prime} N\right.$; $\left.07^{0} 38^{\prime} E\right)$ in the Northern Guinea Savanna ecological zones of Nigeria in a $5 \times 5$ partially balanced lattice design with three replications between July to October, 2014. Each plot consists of two rows 4 $\mathrm{m}$ long, with inter and intra row spacing of $0.75 \mathrm{~m} \mathrm{x}$ $0.25 \mathrm{~m}$ and $1 \mathrm{~m}$ alleys respectively. All agronomic practices were kept uniform in all plots. Data were taken on five centered plants for observations and measurements leaving the plants on either end of the plot to avoid the border effect. Data were recorded for agronomic traits (days to $50 \%$ tasselling (pollen shed), days to $50 \%$ silking, anthesis silking interval, plant height, days to maturity, ear height, $\%$ whole kernel, $\%$ kernel without pericarp damage, density, milling test, moisture content at harvest and grain yield. Analysis of variance was computed using computer statistical software (SAS Institute, 2004) at both $5 \%$ and $1 \%$ probability level of significant.

\section{Combining Ability estimation}

Plot-mean values were used in the Diallel analysis of fixed effects method 2 model 1 (Griffing's. 1956). The model below was used for combining ability analysis across the location: 


\section{RESULTS AND DISCUSSION}

The mean squares due to GCA were highly significant $(P \leq 0.01)$ for days to maturity (27.74), ear length $(8.84 \mathrm{~cm})$ and ear diameter $(22.25 \mathrm{~cm})$ and significant $(p \leq 0.05)$ for plant height $(1501.60 \mathrm{~cm})$, field weight $(1.70 \mathrm{~kg})$, moisture content at harvest $(16.48 \%)$ and yield $\left(10947553.16 \mathrm{kgha}^{-1}\right)$ indicating that the additive gene action contributed more to the expression of these traits. The finding of the present study corroborate with the work of Shushay et al. (2013) who reported significant mean squares due to GCA of lines for grain yield, plant height, ear height and days to anthesis in maize genotypes. The mean squares for SCA were highly significant $(P \leq 0.01)$ for days to maturity (7.49), ear length $(10.06 \mathrm{~cm})$, ear diameter $(26.96 \mathrm{~cm})$ and moisture content at harvest (6.78\%) in maize indicating the preponderance of non-additive gene action in the expression of these traits. Hossein et al. (2014) reported significant mean squares due to GCA and SCA for days to silking, plant height, ear height, 1000-kernel weight, ear length, number of rows per ear, number of leaf and kernel yield maize. Melkamu et al.(2013) reported maize lines shows significant both GCA and SCA for Grain yield, Number of ears per plant, Days to anthesis, days to silking, anthesis silking interval, ear height, plant height, ear position, plant aspect and ear aspect. In quality protein maize diallel analysis, Demissew (2014) reported GCA mean squares were significantly different $(P \leq 0.01)$ for grain yield, Number of ears per plant, Days to anthesis, days to silking, anthesis silking interval, ear height, plant height, ear position, plant aspect and ear aspect while mean squares for SCA were significantly different for Grain yield, number of ears per plant, days to anthesis, days to silking, ear height, plant height, Ear position, Plant aspect and Ear aspect. The mean squares for GCAx location and SCAx location were not significant for all traits except percent whole kernel which showed highly significant GCA $\times$ location interaction. Similar result was reported by Bitew et al. (2017) for grain yield, number of ears per plant, days to anthesis, days to anthesis, days to silking, ear height, plant height, ear position, plant aspect and ear aspect in maize. The GCA values where less than the SCA values for most of kernel quality and agronomic traits in maize lines depicting the importance of non-additive gene action over additive. This agrees with the work of Naazar et al., (2001). The significant ( $P \leq 0.05)$ GCA $x$ location interaction for percent whole kernel suggests that different parental genotypes behaved differently with respect to this trait under different location. This demonstrated the need to select different inbred for hybrid production for specific locations for the affected trait. The non-significant SCA $x$ location interaction for all traits indicated good hybrid performance for the traits repeated over different locations, revealing that these hybrids should be produced over wide range of environment. The GCA to SCA mean square ratio were less than unity for some studied traits. This suggested that non-additive gene action could be more important than additive gene action. The importance of additive gene action for different traits has been reported in several investigators in different times in maize (Dagne et al.,2008; Legesse et al.,2009; Nzuve et al.,2013; Hossein et al.,2014; Mwai et al., 2015).

\section{CONCLUSION}

Significant mean squares due to GCA for all traits and SCA for the most of the traits studied were detected, indicated that both additive and non-additive gene actions contribute to the expression of the traits. The significant GCA x location interaction for percent whole kernel suggesting that different parental genotypes behaved differently with respect to this trait under different locations. This demonstrated the need to select different inbred lines for hybrid production for specific locations for the affected trait. The non-significant SCA $x$ location interaction for all traits indicated a good hybrid performance for the traits repeated over different locations which revealed that these hybrids should be produced over wide range of environment.

Table 1: Origin and Descriptions of the Genotypes

\begin{tabular}{llll}
\hline Genotype & Pedigree & Colour & $\begin{array}{l}\text { Source, } \\
\text { Description }\end{array}$ \\
\hline P1 & P43SRC9FS100-1-1-8-\#1-B1-13-B1-B-B-B-B-B-B-B-B & White & IITA, Dent \\
P2 & $1368 \times H I \times 4269-1368-7-2-B-B-B-B-B$ & White & IITA, Dent \\
P3 & $9071-B-B-B$ & White & IITA, Dent \\
P4 & $($ TZMI501 $\times$ KU1414×501)-1-4-3-1-B-B-B-B-B-B-B-B & White & IITA, Dent \\
P5 & $1368 \times$ ICAL224-1 $\times 1368-3-1-B-B-B-B-B-B-B-B-B-B-B$ & White & IITA, Dent \\
P6 & TZL-COMP3-C2-S2-34-4-1-2-B-B-B-B-B-B-B & White & IITA, Dent \\
\hline
\end{tabular}


Bajopas Volume 10 Number 2 December, 2017

Table 2: Format of analysis of variance (ANOVA) for combining ability of maize inbred lines across locations in 2014 rainy season.

\begin{tabular}{llll}
\hline Source of variation & Df & MS & EMS \\
\hline Crosses & $n[(n-1) / 2]-1$ & $m_{c}$ & $\sigma_{e}^{2}+r \sigma_{c l}^{2}+r l \sigma_{c}^{2}$ \\
$G C A$ & $(n-1)$ & $m_{g}$ & $\sigma_{e}^{2}+r \sigma_{c l}^{2}+r l \sigma_{s}^{2}+r(n+2) \sigma_{g}^{2}$ \\
$S C A$ & $n(n-3) / 2$ & $m_{s}$ & $\sigma_{e}^{2}+r \sigma_{c l}^{2}+r l \sigma_{s}^{2}$ \\
Crosses $\times$ Location & $(l-1)(n[n-1) / 2]-1$ & $m_{c l}$ & $\sigma_{e}^{2}+r \sigma_{c l}^{2}$ \\
GCA $\times$ Location & $(n-1)(l-1)$ & $m_{g l}$ & $\sigma_{e}^{2}+r \sigma_{s l}^{2}+r(n+2) \sigma_{g l}^{2}$ \\
SCA $\times$ Location & $(n(n-3) / 2)(l-1)$ & $m_{s l}$ & $\sigma_{e}^{2}+r \sigma_{s l}^{2}$ \\
Error & $l(r-1)(n[(n+1) / 2]-1$ & $m_{e}$ & $\sigma_{e}^{2}$
\end{tabular}

Key: $\mathrm{n}=$ parent, $\mathrm{c}=$ crosses, $\mathrm{g}=\mathrm{gca}, \mathrm{s}=\mathrm{sca}, \mathrm{l}=$ location, and $\mathrm{e}=$ error. 
Table 3: Mean squares analysis for combining ability for fourteen traits of maize combined across locations

(Samaru and Bagauda) in 2014

\begin{tabular}{|c|c|c|c|c|c|c|c|c|c|c|c|c|c|c|c|}
\hline $\begin{array}{l}\text { Source } \\
\text { of } \\
\text { variation }\end{array}$ & Df & $\begin{array}{l}\text { Days to } \\
\text { Maturity }\end{array}$ & $\begin{array}{l}\text { Plant Height } \\
(\mathrm{cm})\end{array}$ & $\begin{array}{l}\text { Ear } \\
\text { Height } \\
\text { (cm) }\end{array}$ & $\begin{array}{l}\text { Ear } \\
\text { Length } \\
(\mathrm{cm})\end{array}$ & $\begin{array}{l}\text { Ear } \\
\text { Diameter(c } \\
\mathrm{m})\end{array}$ & $\begin{array}{l}\text { Field } \\
\text { Weight } \\
\text { (kg) }\end{array}$ & $\begin{array}{l}\% \text { whole } \\
\text { kernel }\end{array}$ & $\begin{array}{l}\% \text { kernel } \\
\text { with out } \\
\text { Pericarp } \\
\text { damage }\end{array}$ & $\begin{array}{l}\text { Milling } \\
\text { test }\end{array}$ & $\begin{array}{l}\% \text { Moisture } \\
\text { content at } \\
\text { harvest }\end{array}$ & $\begin{array}{l}\text { 100- grain } \\
\text { Weight }(\mathrm{g})\end{array}$ & $\begin{array}{l}\text { Volume } \\
\left(\mathrm{m}^{3}\right)\end{array}$ & $\begin{array}{l}\text { Density } \\
\left(\mathrm{kgm}^{-3}\right)\end{array}$ & $\begin{array}{l}\text { Grain Yield } \\
\left(\mathrm{kgha}^{-1}\right)\end{array}$ \\
\hline Location & 1 & 0.02 & 85.18 & 36.91 & 1.83 & 176.44 & 26.48 & $58652.72^{* *}$ & $2061.13^{* *}$ & 5.75 & $16.32^{*}$ & 8406167 & $100.05^{* *}$ & $\begin{array}{l}530392.70 \\
*\end{array}$ & 3603389 \\
\hline $\begin{array}{l}\text { Replicati } \\
\text { on (loc) }\end{array}$ & 4 & $26.26^{*}$ & $1468.47^{* *}$ & 397.95* & 6.4 & 131.4 & $20.3 * *$ & $3406.72 * *$ & 205.21 & 0.66 & $23.32^{* *}$ & $\begin{array}{l}5555291.00 \\
* *\end{array}$ & $37.51^{*}$ & 183942.3 & $20276536.30 * *$ \\
\hline Parent & 5 & $58.11^{* *}$ & $3604.91 * *$ & $839.97 *$ & $51.10^{* *}$ & 712.05 & 69.76 & 251.36 & 1040.56 & $55.04 * *$ & 4.59 & 11812663 & 46.1 & 383970.2 & $49182618.40 * *$ \\
\hline $\begin{array}{l}\text { Parent } \times \\
\text { Location }\end{array}$ & 5 & 4.24 & 93.87 & 115.99 & 0.47 & $534.4 * *$ & $62.78 * *$ & 837.76 & 494.84 & 2.99 & 7.53 & 5338917 & $47.56 * *$ & 419103.7 & 3676300 \\
\hline $\begin{array}{l}\text { Crosses } \\
\text { GCA } \\
\text { SCA }\end{array}$ & $\begin{array}{l}14 \\
5 \\
9\end{array}$ & $\begin{array}{l}14.73 * * \\
27.74 * * \\
7.49 * *\end{array}$ & $\begin{array}{l}784.02 * \\
1501.60^{*} \\
385.36\end{array}$ & $\begin{array}{l}241.92 \\
282.4 \\
219.43\end{array}$ & $\begin{array}{l}9.63^{* *} \\
8.85^{* *} \\
10.06^{* *}\end{array}$ & $\begin{array}{l}25.28 * * \\
22.25 * * \\
26.96 * *\end{array}$ & $\begin{array}{l}1.19 * \\
1.70^{*} \\
0.91\end{array}$ & $\begin{array}{l}375 \\
566.02 \\
268.88\end{array}$ & $\begin{array}{l}319.47 \\
310.98 \\
324.19\end{array}$ & $\begin{array}{l}5.93 \\
3.01 \\
7.55^{*}\end{array}$ & $\begin{array}{l}10.25^{* *} \\
16.48^{*} \\
6.78^{* *}\end{array}$ & $\begin{array}{l}595657.60 * \\
554271.7 \\
618649.8\end{array}$ & $\begin{array}{l}13.21 \\
7.21 \\
16.53\end{array}$ & $\begin{array}{l}16853.09 \\
10872.15 \\
20175.83\end{array}$ & $\begin{array}{l}7674936.08^{*} \\
10947553.16^{*} \\
5856815\end{array}$ \\
\hline $\begin{array}{l}\text { Crosses } \\
\times \\
\text { Location }\end{array}$ & 14 & 0.33 & 320.57 & 172.84 & 0.21 & 0.01 & 0.4 & $1156.5^{* *}$ & 141.03 & 2.49 & 1.32 & 398421.1 & 15.75 & 21807.16 & 2572765 \\
\hline $\begin{array}{l}\text { Parent } x \\
\text { Cross } x \\
\text { Location }\end{array}$ & 1 & 3.78 & 701.42 & 170.87 & 2.78 & 432.02 & 60.55 & 150.52 & $1020.51 *$ & 0.02 & 3.37 & 871371.6 & $59.76 *$ & $\begin{array}{l}459600.63 \\
*\end{array}$ & 4409629 \\
\hline $\begin{array}{l}\text { GCA } x \\
\text { Location }\end{array}$ & 5 & 0.38 & 229.83 & 188.49 & 0.17 & 0.01 & 0.35 & $2077.97 * *$ & 80.04 & 3.38 & 0.48 & 309116.1 & 13.99 & 14039.34 & 2238177 \\
\hline $\begin{array}{l}\text { SCA } x \\
\text { Location }\end{array}$ & 9 & 0.3 & 370.98 & 164.15 & 0.23 & 0.03 & 0.43 & 644.57 & 174.92 & 2 & 0.26 & 448035 & 16.72 & 26122.61 & 2758646 \\
\hline Error & 80 & 3.27 & 83.8 & 49.2 & 1.19 & 55.97 & 6.69 & 128.85 & 84.99 & 1.22 & 1.3 & 1030289 & 4.96 & 39426.3 & 724272 \\
\hline
\end{tabular}

$*, * *$ significant at $5 \%$ and $1 \%$ levels of probability respectively 


\section{REFERENCES}

Banziger, M. and Diallo, A.O. (2004). Progress in developing drought ad $\mathrm{N}$ stress tolerant maize cultivars for Eastern and Southern Africa. In Friesen, D.K. and Palmer, A.F.E. (eds). Integrated Approaches to Higher Maize Productivity in the New Millenium. Proceedings of the $7^{\text {th }}$ Eastern and Southern Africa Regional Maize Conference, 5-11 February, 2002. CIMMYT/KARI, Nairobi, Kenya. pp. 189-194.

Dagne W, Habtamu Z, Demissew A, Temam H, Harjit S (2008). Combining ability of inbred lines for grain yield and reaction to grey leaf spot disease. East African Journal of Science 2:135145.

Demissew AA (2014). Genetic diversity and combining ability of selected quality protein maize (QPM) inbred lines adapted to the highland agroecology of Ethiopia. A dissertation for the degree of Doctor of Philosophy (PhD) in Plant Breeding. KwaZulu-Natal University. South Africa.

DeVries, J., and G. Toenniessen. (2001). Securing the harvest: biotechnology, breeding and seed systems for African crops. CABI Publishing, Wallingford, UK.

Dilip, K., Narayan T. and Adatya., N.J.(2013). Nutritional,Medicinal, and Economical importanceof Corn: A Mini Review Research Journal of Pharmaceutical Sciences, 2[7]:7-8.

FAO. (2009). 1.02 billion people hungry. http://www.fao.org/news/story/en/item/20568 icode/

FAOSTAT (2014). FAO Statistics yearbook. Food and Agriculture Organisation.FAO, Rome.

Griffing, J.B. (1956). Concept of general and specific combining ability in relation to diallel systems. Australian Journal of Biological Science. 9:463493.

Hallauer, A.R. (1997). Maize improvement. In: Kang, M.S. (ed.) Crop Improvement for the $21^{\text {st }}$ Century. Research Signpost, Trivandrum, India. pp. 15-27.

Hossein, Haddadia, Maqsadollah Eesmaeilovband, Rajab,Choukan. (2014). Diallel analyses of some agronomic traits in maize (Zea May L.). International journal of plant, animal and environmental sciences (volume-4, Issue 1:2014).

Legesse W, Pixley KV,Botha AM (2009). Combining ability and heterotic grouping of highland transition maize inbred lines. Maydica 54:1-9.
Melkamu E, Tadsse D, Yigzaw D (2013).Combing ability, gene action and heterosis estimation in quality protein maize. International Journal Science Research Publication 3(6):1- 17.

Mwai O, Ralia KM, Musalia M (2015). Combining abilities of maize inbred lines for grey leaf spot (GLS), grain yield and selected agronomic traits in Kenya. International Journal of Agricultural Science5(4):645-650

Naazar, A., Mlik, S.N., Khurram, B. and Yasin, B. (2001). Combining ability in $F_{2}$ and $F_{3}$ generations for early maturity and agronomic traits in groundnut (Arachis hypogaea L.). Pakistan Journal of Botany, 33(1): 93-99.

Naazar, Ali, Malik, S.N., Bashir, K. and Mirza, M.Y. (2001). Genetic variability, heritability and correlation studies in groundnut. Sarhad Journal of Agriculture, 16: 533-536.

Nzuve F, Githiri S, Mukunya DM, Gethi J (2013). Combining abilities of maize inbred lines for grey leaf spot (GLS), grain yield and selected agronomic traits in Kenya. Journal of Plant Breeding, Crop Science 5(3):41-47.

Paliwal, R.L. and Smith, M.E. (2002). Tropical maize: Innovative approaches for sustainable productivity and crop production increases. In: Kang, M.S. (ed.) Crop Improvement: Challenges in the Twenty-first Century. Food Product Press, an imprint of Haworth Press, Binghamton, New York. pp. 43-47.

SAS Institute Inc. (2004). SAS/STAT ${ }^{\circledR}$ Users Guide. Version 9.0. SAS Institute Inc. Cary, N.C.

Shushay W, Habtamu Z, Dagne W (2013). Line x tester analysis of maize inbred lines for grain yield and yield related traits. Asian Journal of Plant Science Research 3(5):12-19.

USAID. (2010). Packages of practice for maize production. United States Agency for International Development. pp. 1-2.

USDA. (2010). World of corn. United States Department of Agriculture, Washington, DC. Pp. 7-8

USDA. (2018). World Agricultural Production. United States Department of Agriculture Foreign Agricultural Service Circular Series WAP 2-18 February 2018 World Agricultural Production USDA , Washington, DC. 